\title{
EFFECTS OF MULTI-TIME SCALES CLIMATE CHANGES ON TOBACCO-PLANTING COUNTIES IN CHENZHOU CITY OF HUNAN PROVINCE
}

\author{
Daiwei Pan, Quan Zhong ${ }^{1}$, Yahua Liao ${ }^{2}$, Bin He ${ }^{1}$, Wujin Li ${ }^{1}$, Hong Jian ${ }^{1}$, \\ Zhihong He ${ }^{1}$, Zhihui CaO ${ }^{1}$ and Yansong Xiao ${ }^{1 *}$ \\ Institute of Soil Science, Chinese Academy of Sciences, Nanjing, Jiangsu, China
}

Keywords: Sunshine time, Temperature, Precipitation, Multi-time scale, Tobacco, Chenzhou city

\begin{abstract}
To provide scientific instruction in predicting the climate changes and adopting the suitable measures for field cultivation and management of tobacco, the changes of main climatic parameters on multi-time scales in the six tobacco-planting counties of Chenzhou city in China were studied. Sunshine hours (S) in the six counties had significant positive linear correlation with year (from 1980 to 2020) and precipitation (P) changed irregularly on the scales of year, field-growth period, and rooting and flourishing stages, and they changed significantly in maturing stage. Sunshine hours (S) in the six counties had significant positive linear correlation with year on the scale of rooting stage, changed irregular with year on the scale of year, and showed different change tendencies in different counties in flourishing and maturing stages. On the scale of field-growth period, the daily cumulative temperature $(\mathrm{T})$ was lower than the optimal value in rooting and flourishing stages, but higher than the optimal value in maturing stage.
\end{abstract}

\section{Introduction}

As the most typical region of Nanling hill ecological zone of tobacco-planting with the aroma style of burnt-pure sweet in China (Luo et al. 2019), Chenzhou City is the largest tobacco-planting region in Hunan province, accounting for about $1 / 3\left(2.67 \times 10^{4} \mathrm{hm}^{2}\right)$ of the total tobacco-planting area in Hunan (Luo et al. 2017).

Climate conditions influence or even determine the growth, yield and quality of tobacco ( $(\mathrm{Li}$ 2000, Jin et al. 2009, Peng et al. 2009, Song 2010, Wu et al. 2011, Li et al. 2015). The previous studies related with tobacco-growth in Chenzhou City showed that, according to the optimal values of climate parameters for the planting of the high-quality tobacco, the temperature there was feasible but the sunshine hour was unsuitable a bit in tobacco field-growth period, and the precipitation was unfavorable in rooting stage but suitable in flourishing and maturing stages (Rong 2013). Low temperature and less sunlight hours in early growth stages and high temperature in maturing stage were the major factors for the occurrence of "high temperature forced early-maturity" (Kuang 2009). which could weaken the quality and the aroma style of tobacco (Chen et al. 2015a, 2015b). Different climate parameters changed differently at different time scales (year, tobacco field-growth period and growth stage), and sunshine hour and precipitation changed negatively while precipitation changed positively in maturing stage for tobacco growth (Kong et al. 2020).

But the above reports seldom considered the changes of climate parameters with time (Kuang 2009, Rong 2013, Chen et al. 2015a, 2015b), or only focused on one tobacco-planting counties in Chenzhou City (Chen et al. 2015b, Kong et al. 2020), little information so far is available on the changes of climate parameters with multi-time scales or in other tobacco-planting counties. Therefore, in this study the climate data from 1980 to 2020 of the all tobacco-planting counties in

*Author for correspondence: <35149517@qq.com>. ${ }^{1}$ Chenzhou Tobacco Company of Hunan Province, Chenzhou, Hunan, China. ${ }^{2}$ Hunan Provincial Tobacco Company, Changsha, Hunan, China. 
Chenzhou City were used to analyze the characteristics, changes and tobacco-planting suitability of main climate parameters on different scales of time (year, tobacco field-growth period and growth stage) in order to help the prediction of climate changes and the adoption of suitable measures for field cultivation and management of tobacco.

\section{Methods and Materials}

Chenzhou City is located in the southeast of Hunan province, between $112^{\circ} 13^{\prime}$ to $114^{\circ} 14^{\prime}$ in east longitude and $24^{\circ} 53^{\prime}$ to $26^{\circ} 50^{\prime}$ in north latitude with a total area of $1.94 \times 10^{4} \mathrm{~km}^{2}$, which belongs to subtropical monsoon humid climate with annual mean temperature of $15.4 \sim 18.3^{\circ} \mathrm{C}$, cumulative sunshine hrs of $1510.3 \sim 1764.3 \mathrm{hrs}$, precipitation of $1320.3 \sim 1654.7 \mathrm{~mm}$ and frost-free season of 235 296 d (Rong 2013). The altitude of Chenzhou City ranges from 70 to $2061 \mathrm{~m}$, and the landform is complex, varies with mountains and hills accounting for about 3/4 of the total area. The main soil types are red soil, yellow red soil and paddy soil (Hunan Agriculture Department 1989 ), and the total area of cultivated land is $30.96 \times 10^{4} \mathrm{hm}^{2}$ with the areas of $25.94 \times 10^{4} \mathrm{hm}^{2}$ of paddy fields and $5.02 \times 10^{4} \mathrm{hm}^{2}$ for dry fields (Chenzhou Municipal Bureau of Statistic 2018). Tobacco is mainly cultivated in paddy fields under the tobacco-late rice rotation.

The climate data from January 1 of 1980 to July 31 of 2020 which include daily cumulative sunshine hours (S), daily mean temperature $(\mathrm{T})$ and daily cumulative precipitation $(\mathrm{P})$ were collected from the national meteorological stations in the six tobacco-planting counties in Chenzhou City (Table 1).

Tobacco field-growth period in Chenzhou City is generally from March 10 to July 20, in which the rooting, flourishing and maturing stages are from March 10 to April 20, from April 21 to May 30 and from June 1 to July 20, respectively (Yu and He 2006, Xiao et al. 2007).

For data processing, statistical analysis and modeling IBM Statistics SPSS 20.0 were used (Xie et al. 2006).

Table 1. Information of national meteorological stations in six tobacco-planting counties in Chenzhou city.

\begin{tabular}{llccc}
\hline Station number & County & Longitude & Latitude & Altitude (m) \\
\hline 57881 & Anren (AR) & $113^{\circ} 15^{\prime} 31^{\prime \prime}$ & $26^{\circ} 42^{\prime} 50^{\prime \prime}$ & 101.8 \\
57973 & Guiyang (GY) & $112^{\circ} 43^{\prime} 29^{\prime \prime}$ & $25^{\circ} 44^{\prime} 58^{\prime \prime}$ & 329.1 \\
57974 & Jiahe (JH) & $112^{\circ} 21^{\prime} 55$ & $25^{\circ} 34^{\prime} 53^{\prime \prime}$ & 214.5 \\
57978 & Linwu (LW) & $112^{\circ} 32^{\prime} 47$ & $25^{\circ} 16^{\prime} 23^{\prime \prime}$ & 292.0 \\
57976 & Yizhang (YZ) & $112^{\circ} 56^{\prime} 26$ & $25^{\circ} 24^{\prime} 21^{\prime \prime}$ & 222.8 \\
57887 & Yongxing (YX) & $113^{\circ} 06^{\prime} 52$ & $26^{\circ} 07^{\prime} 37^{\prime \prime}$ & 167.6 \\
\hline
\end{tabular}

\section{Results and Discussion}

The statistical information of $\mathrm{S}, \mathrm{T}$ and $\mathrm{P}$ on different scales of time is presented in Table 2. For the six tobacco-planting counties in Chenzhou City, on the scale of year, S ranged from 1407 to $1534 \mathrm{hrs}$ with a mean of $1463 \mathrm{hrs}$, T was from 17.7 to $18.7^{\circ} \mathrm{C}$ with a mean of $18.2^{\circ} \mathrm{C}$, and $\mathrm{P}$ was from 1413 to $1511 \mathrm{~mm}$ with a mean of $1465 \mathrm{~mm}$. On the scale of field-growth period, $\mathrm{S}$ was from 488 to $595 \mathrm{hrs}$ with a mean of $545 \mathrm{hrs}$, T was from 21.6 to $22.2^{\circ} \mathrm{C}$ with a mean of $22.0^{\circ} \mathrm{C}$, and $\mathrm{P}$ was from 758 to $827 \mathrm{~mm}$ with a mean of $800 \mathrm{~mm}$. On the scale of rooting stage, $\mathrm{S}$ was from 82 to $113 \mathrm{hrs}$ with a mean of $96 \mathrm{hrs}$, $\mathrm{T}$ was from 14.9 to $15.8^{\circ} \mathrm{C}$ with a mean of $15.4^{\circ} \mathrm{C}$, and $\mathrm{P}$ was from 
227 to $250 \mathrm{~mm}$ with a mean of $240 \mathrm{~mm}$. On the scale of flourishing stage, $\mathrm{S}$ was from 138 to 174 hrs with a mean of $155 \mathrm{hrs}$, T was from 21.8 to $22.6^{\circ} \mathrm{C}$ with a mean of $22.3^{\circ} \mathrm{C}$, and $\mathrm{P}$ was from 258 to $275 \mathrm{~mm}$ with a mean of $265 \mathrm{~mm}$. On the scale of the maturing stage, $\mathrm{S}$ was from 290 hes to $309 \mathrm{hrs}$ with a mean of $294 \mathrm{hrs}$, T was from 26.7 to $27.8^{\circ} \mathrm{C}$ with a mean of $27.3^{\circ} \mathrm{C}$, and $\mathrm{P}$ was from 269 to $314 \mathrm{~mm}$ with a mean of $294 \mathrm{~mm}$.

Table 2. Statistical descriptions of main climate parameters on different scales of time. $(n=40)^{*}$ (AR, GY, JH, LW, YZ and YX have been explained in Table 1).

\begin{tabular}{|c|c|c|c|c|c|c|c|c|c|c|}
\hline \multirow[t]{2}{*}{ Time scale } & \multirow[t]{2}{*}{ County } & \multicolumn{3}{|c|}{ S (h) } & \multicolumn{3}{|c|}{$\mathrm{T}\left({ }^{\circ} \mathrm{C}\right)$} & \multicolumn{3}{|c|}{$\mathrm{P}(\mathrm{mm})$} \\
\hline & & Range & Mean \pm Sd & $\begin{array}{l}\text { C.V. } \\
(\%)\end{array}$ & Range & Mean \pm Sd & $\begin{array}{l}\text { C.V. } \\
(\%)\end{array}$ & Range & Mean \pm Sd & $\begin{array}{l}\text { C.V. } \\
(\%)\end{array}$ \\
\hline \multirow[t]{6}{*}{ Year } & $\mathrm{AR}$ & $1189-1782$ & $1453 \pm 156$ & 10.72 & $16.9-19.4$ & $18.2 \pm 0.6$ & 3.29 & $913-2177$ & $1511 \pm 311$ & 20.58 \\
\hline & GY & $1178-1840$ & $1534 \pm 162$ & 10.59 & $16.2-18.8$ & $17.7 \pm 0.7$ & 3.66 & $1023-2095$ & $1487 \pm 245$ & 16.50 \\
\hline & $\mathrm{JH}$ & $981-1864$ & $1407 \pm 196$ & 13.93 & $17.3-19.4$ & $18.4 \pm 0.5$ & 2.86 & $967-2063$ & $1413 \pm 252$ & 17.82 \\
\hline & LW & $1080-2027$ & $1529 \pm 218$ & 14.25 & $16.8-18.9$ & $18.1 \pm 0.5$ & 2.62 & $942-2137$ & $1454 \pm 293$ & 20.15 \\
\hline & YZ & $1086-1732$ & $1431 \pm 139$ & 9.69 & 17.4-19.7 & $18.7 \pm 0.6$ & 3.00 & $1002-1897$ & $1453 \pm 233$ & 16.05 \\
\hline & YX & $1202-1685$ & $1425 \pm 122$ & 8.59 & $16.7-19.0$ & $18.1 \pm 0.6$ & 3.20 & $923-2253$ & $1473 \pm 278$ & 18.86 \\
\hline \multirow[t]{6}{*}{ Field period } & $\mathrm{AR}$ & $338-693$ & $556 \pm 78$ & 14.05 & $20.6-23.8$ & $22.1 \pm 0.7$ & 3.38 & $442-1293$ & $821 \pm 214$ & 26.02 \\
\hline & GY & $380-769$ & $595 \pm 79$ & 13.29 & $20.1-23.3$ & $21.6 \pm 0.8$ & 3.62 & $499-1247$ & $789 \pm 166$ & 20.97 \\
\hline & $\mathrm{JH}$ & $357-303$ & $538 \pm 107$ & 19.85 & $20.7-23.7$ & $22.2 \pm 0.7$ & 3.04 & $451-1234$ & $758 \pm 156$ & 20.60 \\
\hline & LW & 303-904 & $541 \pm 124$ & 22.93 & $20.4-22.9$ & $21.8 \pm 0.6$ & 2.93 & $516-1231$ & $827 \pm 171$ & 20.67 \\
\hline & $\mathrm{YZ}$ & $314-611$ & $488 \pm 68$ & 13.98 & $20.8-23.7$ & $22.2 \pm 0.7$ & 3.20 & $500-1205$ & $811 \pm 161$ & 20.17 \\
\hline & YX & $355-695$ & $550 \pm 66$ & 12.06 & $20.4-23.3$ & $21.9 \pm 0.7$ & 3.24 & $444-1325$ & $794 \pm 180$ & 22.67 \\
\hline \multirow{6}{*}{$\begin{array}{l}\text { Rooting } \\
\text { stage }\end{array}$} & $\mathrm{AR}$ & $45-185$ & $96 \pm 32$ & 33.27 & $10.8-18.3$ & $15.1 \pm 1.6$ & 10.68 & $92-531$ & $248 \pm 96$ & 38.58 \\
\hline & GY & $36-215$ & $113 \pm 39$ & 34.86 & $10.2-18.1$ & $14.9 \pm 1.7$ & 11.59 & $94-540$ & $250 \pm 91$ & 36.54 \\
\hline & $\mathrm{JH}$ & $33-190$ & $95 \pm 39$ & 40.91 & $11.3-18.7$ & $15.7 \pm 1.6$ & 10.30 & $82-446$ & $227 \pm 83$ & 36.84 \\
\hline & LW & $23-238$ & $96 \pm 49$ & 51.26 & $11.4-18.3$ & $15.6 \pm 1.5$ & 9.63 & $76-477$ & $228 \pm 96$ & 41.88 \\
\hline & $\mathrm{YZ}$ & $33-172$ & $82 \pm 31$ & 37.78 & $11.7-18.8$ & $15.8 \pm 1.5$ & 9.60 & $77-527$ & $240 \pm 97$ & 40.42 \\
\hline & YX & $36-192$ & $95 \pm 34$ & 36.47 & 11.1-18.1 & $15.2 \pm 1.5$ & 10.00 & $113-477$ & $246 \pm 87$ & 35.54 \\
\hline \multirow{6}{*}{$\begin{array}{l}\text { Flourishing } \\
\text { stage }\end{array}$} & $\mathrm{AR}$ & $97-241$ & $163 \pm 36$ & 22.23 & $20.5-25.1$ & $22.4 \pm 1.0$ & 4.33 & $98-538$ & $259 \pm 97$ & 37.34 \\
\hline & GY & $92-249$ & $174 \pm 39$ & 22.45 & $19.9-24.5$ & $21.8 \pm 1.0$ & 4.55 & $108-477$ & $258 \pm 81$ & 31.41 \\
\hline & $\mathrm{JH}$ & $68-256$ & $152 \pm 47$ & 31.01 & $20.7-25.1$ & $22.6 \pm 0.9$ & 4.10 & $118-409$ & $263 \pm 70$ & 26.47 \\
\hline & LW & $72-375$ & $152 \pm 57$ & 37.36 & $20.5-24.7$ & $22.1 \pm 0.9$ & 3.99 & $143-494$ & $275 \pm 84$ & 30.01 \\
\hline & $\mathrm{YZ}$ & $85-211$ & $138 \pm 32$ & 23.08 & $20.9-24.9$ & $22.5 \pm 0.9$ & 4.02 & $121-441$ & $275 \pm 84$ & 30.45 \\
\hline & YX & $91-219$ & $153 \pm 34$ & 22.10 & $20.2-24.6$ & $22.1 \pm 0.9$ & 4.27 & $125-495$ & $258 \pm 74$ & 28.81 \\
\hline \multirow{6}{*}{$\begin{array}{l}\text { Maturing } \\
\text { stage }\end{array}$} & $\mathrm{AR}$ & $168-415$ & $297 \pm 57$ & 19.26 & $26.2-29.6$ & $27.8 \pm 0.8$ & 2.83 & $58-757$ & $314 \pm 162$ & 51.56 \\
\hline & GY & $181-438$ & $309 \pm 56$ & 18.01 & $25.1-29.1$ & $27.0 \pm 0.8$ & 2.86 & $58-619$ & $282 \pm 124$ & 44.05 \\
\hline & $\mathrm{JH}$ & $174-402$ & $291 \pm 60$ & 20.70 & $25.7-29.6$ & $27.5 \pm 0.7$ & 2.68 & $68-515$ & $269 \pm 113$ & 42.12 \\
\hline & LW & $151-410$ & $294 \pm 54$ & 18.52 & $25.2-28.3$ & $26.7 \pm 0.6$ & 2.31 & $113-652$ & $314 \pm 133$ & 42.48 \\
\hline & $\mathrm{YZ}$ & $120-641$ & $297 \pm 120$ & 40.38 & $25.6-29.2$ & $27.3 \pm 0.7$ & 2.47 & $120-641$ & $297 \pm 120$ & 40.38 \\
\hline & YX & 77-796 & $290 \pm 149$ & 51.27 & $25.7-29.2$ & $27.4 \pm 0.8$ & 2.84 & 77-796 & $290 \pm 149$ & 51.27 \\
\hline
\end{tabular}

"The significance of differences in the same climate parameter between different regions was not marked in the Table because the emphasis of this study is on the changes of climate parameters and the assessment on tobacco-growth suitability and the possible difference in a same climate parameter between the six tobacco-planting counties is naturally attributed to the spatial distribution.

Sunshine hours showed moderate variation in most cases (C.V.(\%) was 10 100\%, Table 2) except in weak variation (C.V.(\%) was $<10 \%$, Table 2). In YZ and YX on the scale of year, T were mostly in weak variation except in moderate variation in LW and $\mathrm{YZ}$ on the scale of rooting stage, while $\mathrm{P}$ were all in moderate variation on all the scales of time. The variation of $\mathrm{P}$ was the largest, 
followed by $\mathrm{S}$ and T, C.V. (\%) of S, T and P ranged from $16.05 \sim 20.58 \%, 8.59 \sim 14.25 \%$ and $2.62 \sim 3.66 \%$ with the mean of $18.33,11.30$ and $3.11 \%$, respectively on the scale of year, from $20.17 \sim 26.02 \%, 12.06 \sim 22.93 \%$ and $2.93 \sim 3.62 \%$ with the mean of $21.85,16.03$ and $3.24 \%$, respectively on the scale of field period, from $35.54 \sim 41.88 \%, 33.27 \sim 51.26 \%$ and $9.60 \sim 11.59 \%$ with the mean of $38.30,39.09$ and $10.30 \%$, respectively on the scale of rooting stage, from $26.47 \sim 37.34 \%, 22.10 \sim 37.36 \%$ and $3.99 \sim 4.55 \%$ with the mean of $30.75,26.37$ and $4.21 \%$, respectively on the scale of flourishing stage, from $40.38 \sim 51.56 \%, 17.70 \sim 20.70 \%$ and $2.31 \sim 2.86 \%$ with the mean of $45.31,19.02$ and $2.67 \%$, respectively on the scale of maturing stage.

Table 3 shows Pearson correlation coefficients of S, T and P with time on the scales of year, tobacco field-growth period and different growth stages. It can be seen that $\mathrm{T}$ changed more regularly than $\mathrm{S}$ and $\mathrm{P}$ because $\mathrm{T}$ had significant positive correlation on the scale of year, tobacco field-growth period, rooting and flourishing stages. On the scale of year, in all counties, $\mathrm{T}$ had significant positive correlation with year $(\mathrm{p}=0.000)$, while $\mathrm{S}$ and $\mathrm{P}$ had no significant correlation with year $(\mathrm{p}=0.063 \sim 0.830$ for $\mathrm{S}$ and $0.313 \sim 0.865$ for $\mathrm{T})$. On the scale of field-growth period, $\mathrm{T}$ still had significant positive correlation with year $(\mathrm{p}=0.000)$ and $\mathrm{P}$ still had no significant positive correlation with year $(\mathrm{p}=0.182 \sim 0.650)$, while $\mathrm{S}$ had positive correlation with year only in LW $(\mathrm{p}=0.014)$. On the scale of rooting stage, both $\mathrm{S}$ and $\mathrm{T}$ had significant positive correlation with year $(\mathrm{p}=0.000 \sim 0.002$ for $\mathrm{S}$ and 0.000 for $\mathrm{T})$, while $\mathrm{P}$ had no significant correlation with year $(\mathrm{p}=0.148 \sim 0.675)$. On the scale of flourishing stage, $\mathrm{S}, \mathrm{T}$ and $\mathrm{P}$ showed the similar change tendencies as on the scale of field-growth period, $\mathrm{T}$ still had significant positive correlation with year $(\mathrm{p}=0.001 \sim 0.009)$ and $\mathrm{P}$ still had no significant positive correlation with year $(0.271 \sim 0.981)$, while $\mathrm{S}$ had positive correlation with year in only $\mathrm{LW}(\mathrm{p}=0.035)$. On the scale of maturing stage, $\mathrm{S}$ had significant negative correlation with year in $\mathrm{AR}, \mathrm{YZ}$ and $\mathrm{YX}(\mathrm{p}=0.023,0.017$ and 0.001 , respectively), $\mathrm{T}$ had significant positive correlation with year only in $\mathrm{YZ}(\mathrm{p}=0.014)$, while $\mathrm{P}$ had significant positive correlation with year in $\mathrm{AR}, \mathrm{JH}$ and $\mathrm{YZ}(\mathrm{p}=0.020,0.029$ and 0.024 , respectively).

Table 4 shows the optimal regression models of climate parameters on different scales of time which were obtained with the module of Curve Estimation in SPSS software. It can be seen that the linear regression model could describe well the changes of the climate parameters on different scales of time. Meanwhile, the accuracy was the highest for the climate models on the scale of year $\left(R^{2}\right.$ was $0.453 \sim 0.663$ with a mean of 0.584 and $\left.p=0.000\right)$, followed by the climate models on the scale of field period ( $\mathrm{R}^{2}$ was $0.145 \sim 0.591$ with a mean of 0.473 and $\left.\mathrm{p}=0.000 \sim 0.014\right)$, and the climate models had the lowest accuracy on the scale of growth stage $\left(\mathrm{R}^{2}\right.$ was $0.117 \sim 0.245$ with a mean of 0.146 and $\mathrm{p}=0.001 \sim 0.029)$. On the other hand, the accuracies of the climate models were higher in rooting stage $\left(\mathrm{R}^{2}\right.$ was $0.212 \sim 0.468$ with a mean of 0.363 and $\mathrm{p}=0.000 \sim 0.002$ with a mean of 0.000) than those in flourishing and maturing stages $\left(\mathrm{R}^{2}\right.$ was $0.109 \sim 0.265$ with a mean of 0.187 and $0.117 \sim 0.245$ with a mean of $0.146, \mathrm{p}=0.001 \sim 0.035$ with a mean of 0.009 and $0.001 \sim 0.029$ with a mean of 0.018).

The optimal temperature for tobacco growth is $25 \sim 28^{\circ} \mathrm{C}$ (Xiao et al. 2006). As shown in Table 2 , in the six counties in Chenzhou City, Temperature in rooting stage $\left(14.9 \sim 15.8^{\circ} \mathrm{C}\right)$ and in flourishing stage $\left(21.8 \sim 22.5^{\circ} \mathrm{C}\right)$ was lower than the optimal value, but $\mathrm{T}$ was higher than the optimal value in maturing stage $\left(28.3 \sim 29.6^{\circ} \mathrm{C}\right)$. The optimal sunshine hour and precipitation for tobacco growth is 500 700 hrs (Xie et al. 2006) and 700 800 mm (Yang et al. 1987) in field-growth period. It has been found that, in the six counties in Chenzhou City, S was 488 hrs in YZ, lower than the optimal values (Table 2), but $\mathrm{S}$ in other counties (538 595 hrs), was within 
Table 3. Pearson correlation coefficients between main climatic parameters with year (n=40). (S, T, P, AR, GY, JH, LW, YZ and YX as mentioned in the text and Table 1).

\begin{tabular}{|c|c|c|c|c|c|c|c|c|}
\hline & Parameter & Correlation & $\mathrm{AR}$ & GY & $\mathrm{JH}$ & LW & $\mathrm{YZ}$ & YX \\
\hline \multirow[t]{6}{*}{ Year } & \multirow[t]{2}{*}{$\mathrm{S}$} & $\begin{array}{l}\text { Pearson correlation } \\
\text { coefficient }\end{array}$ & 0.035 & 0.121 & 0.073 & 0.297 & -0.034 & -0.161 \\
\hline & & Sig. (2-tailed) & 0.830 & 0.456 & 0.656 & 0.063 & 0.837 & 0.322 \\
\hline & \multirow[t]{2}{*}{$\mathrm{T}$} & $\begin{array}{l}\text { Pearson correlation } \\
\text { coefficient }\end{array}$ & $0.797^{* *}$ & $0.799^{* *}$ & $0.673^{* *}$ & $0.706^{* *}$ & $0.785^{* *}$ & $0.814^{* *}$ \\
\hline & & Sig. (2-tailed) & 0.000 & 0.000 & 0.000 & 0.000 & 0.000 & 0.000 \\
\hline & \multirow[t]{2}{*}{$\mathrm{P}$} & $\begin{array}{l}\text { Pearson correlation } \\
\text { coefficient }\end{array}$ & 0.113 & 0.048 & 0.096 & 0.164 & 0.029 & -0.028 \\
\hline & & Sig. (2-tailed) & 0.486 & 0.770 & 0.558 & 0.313 & 0.860 & 0.865 \\
\hline \multirow[t]{6}{*}{$\begin{array}{l}\text { Whole field } \\
\text { period }\end{array}$} & \multirow[t]{2}{*}{$\mathrm{S}$} & $\begin{array}{l}\text { Pearson correlation } \\
\text { coefficient }\end{array}$ & -0.038 & 0.261 & 0.064 & $0.381^{*}$ & -0.047 & -0.158 \\
\hline & & Sig. (2-tailed) & 0.812 & 0.100 & 0.690 & 0.014 & 0.769 & 0.323 \\
\hline & \multirow[t]{2}{*}{$\mathrm{T}$} & $\begin{array}{l}\text { Pearson correlation } \\
\text { coefficient }\end{array}$ & $0.736^{* *}$ & $0.769^{* *}$ & $0.669^{* *}$ & $0.698^{* *}$ & $0.745^{* *}$ & $0.736^{* *}$ \\
\hline & & Sig. (2-tailed) & 0.000 & 0.000 & 0.000 & 0.000 & 0.000 & 0.000 \\
\hline & \multirow[t]{2}{*}{$\mathrm{P}$} & $\begin{array}{l}\text { Pearson correlation } \\
\text { coefficient }\end{array}$ & 0.131 & 0.093 & 0.213 & 0.228 & 0.120 & 0.073 \\
\hline & & Sig. (2-tailed) & 0.414 & 0.561 & 0.182 & 0.151 & 0.456 & 0.650 \\
\hline \multirow[t]{6}{*}{$\begin{array}{l}\text { Rooting } \\
\text { stage }\end{array}$} & \multirow[t]{2}{*}{$\mathrm{S}$} & $\begin{array}{l}\text { Pearson correlation } \\
\text { coefficient }\end{array}$ & $0.533^{* *}$ & $0.647^{* *}$ & $0.555^{* *}$ & $0.636^{* *}$ & $0.461^{* *}$ & $0.549^{* *}$ \\
\hline & & Sig. (2-tailed) & 0.000 & 0.000 & 0.000 & 0.000 & 0.002 & 0.000 \\
\hline & \multirow[t]{2}{*}{$\mathrm{T}$} & $\begin{array}{l}\text { Pearson correlation } \\
\text { coefficient }\end{array}$ & $0.684^{* *}$ & $0.666^{* *}$ & $0.626^{* *}$ & $0.550^{* *}$ & $0.598^{* *}$ & $0.658^{* *}$ \\
\hline & & Sig. (2-tailed) & 0.000 & 0.000 & 0.000 & 0.000 & 0.000 & 0.000 \\
\hline & \multirow[t]{2}{*}{$\mathrm{P}$} & $\begin{array}{l}\text { Pearson correlation } \\
\text { coefficient }\end{array}$ & -0.230 & -0.158 & -0.068 & -0.077 & -0.082 & -0.183 \\
\hline & & Sig. (2-tailed) & 0.148 & 0.323 & 0.675 & 0.634 & 0.612 & 0.253 \\
\hline \multirow[t]{6}{*}{$\begin{array}{l}\text { Flourishing } \\
\text { stage }\end{array}$} & \multirow[t]{2}{*}{$\mathrm{S}$} & $\begin{array}{l}\text { Pearson correlation } \\
\text { coefficient }\end{array}$ & 0.010 & 0.138 & 0.052 & $0.330^{*}$ & 0.066 & -0.090 \\
\hline & & Sig. (2-tailed) & 0.951 & 0.390 & 0.748 & 0.035 & 0.682 & 0.576 \\
\hline & \multirow[t]{2}{*}{$\mathrm{T}$} & $\begin{array}{l}\text { Pearson correlation } \\
\text { coefficient }\end{array}$ & $0.401^{* *}$ & $0.433^{* *}$ & $0.501^{* *}$ & $0.393^{*}$ & $0.514^{* *}$ & $0.430^{* *}$ \\
\hline & & Sig. (2-tailed) & 0.009 & 0.005 & 0.001 & 0.011 & 0.001 & 0.005 \\
\hline & \multirow[t]{2}{*}{$\mathrm{P}$} & $\begin{array}{l}\text { Pearson correlation } \\
\text { coefficient }\end{array}$ & -0.087 & -0.168 & -0.047 & 0.004 & -0.176 & 0.063 \\
\hline & & Sig. (2-tailed) & 0.589 & 0.294 & 0.770 & 0.981 & 0.271 & 0.695 \\
\hline \multirow[t]{6}{*}{$\begin{array}{l}\text { Maturing } \\
\text { stage }\end{array}$} & \multirow[t]{2}{*}{$\mathrm{S}$} & $\begin{array}{l}\text { Pearson correlation } \\
\text { coefficient }\end{array}$ & $-0.355^{*}$ & -0.185 & -0.287 & -0.051 & $-0.370^{*}$ & $-0.495^{* *}$ \\
\hline & & Sig. (2-tailed) & 0.023 & 0.248 & 0.069 & 0.749 & 0.017 & 0.001 \\
\hline & \multirow[t]{2}{*}{$\mathrm{T}$} & $\begin{array}{l}\text { Pearson correlation } \\
\text { coefficient }\end{array}$ & 0.269 & 0.300 & 0.100 & 0.283 & $0.380^{*}$ & 0.298 \\
\hline & & Sig. (2-tailed) & 0.089 & 0.057 & 0.533 & 0.074 & 0.014 & 0.059 \\
\hline & \multirow[t]{2}{*}{$\mathrm{P}$} & $\begin{array}{l}\text { Pearson correlation } \\
\text { coefficient }\end{array}$ & $0.361^{*}$ & 0.271 & $0.342^{*}$ & 0.307 & $0.352^{*}$ & 0.282 \\
\hline & & Sig. (2-tailed) & 0.020 & 0.086 & 0.029 & 0.051 & 0.024 & 0.074 \\
\hline
\end{tabular}


Table 4. Optimal regression models of climate parameters on different scales of time.

\begin{tabular}{|c|c|c|c|c|c|c|}
\hline Scale & Parameter & County & Model & $\mathrm{R}^{2}$ & Sig. & RSME \\
\hline \multirow[t]{6}{*}{ Year } & \multirow[t]{6}{*}{$\mathrm{T}$} & $\mathrm{AR}$ & $y=0.041 x-63.444$ & 0.636 & 0.000 & 0.37 \\
\hline & & GY & $y=0.044 x-71.017$ & 0.638 & 0.000 & 0.40 \\
\hline & & $\mathrm{JH}$ & $y=0.030 x-42.317$ & 0.453 & 0.000 & 0.40 \\
\hline & & LW & $y=0.029 x-39.198$ & 0.499 & 0.000 & 0.34 \\
\hline & & $\mathrm{YZ}$ & $y=0.038 x-56.407$ & 0.616 & 0.000 & 0.35 \\
\hline & & YX & $y=0.040 x-62.525$ & 0.663 & 0.000 & 0.34 \\
\hline \multirow[t]{7}{*}{ Field period } & $\mathrm{S}$ & LW & $y=3.944 x-7347.460$ & 0.145 & 0.014 & 116.29 \\
\hline & \multirow[t]{6}{*}{$\mathrm{T}$} & AR & $y=0.046 x-69.662$ & 0.541 & 0.000 & 0.51 \\
\hline & & GY & $y=0.050 x-78.516$ & 0.591 & 0.000 & 0.50 \\
\hline & & $\mathrm{JH}$ & $y=0.038 x-53.371$ & 0.448 & 0.000 & 0.51 \\
\hline & & LW & $y=0.037 x-52.530$ & 0.488 & 0.000 & 0.46 \\
\hline & & $\mathrm{YZ}$ & $y=0.044 x-66.030$ & 0.554 & 0.000 & 0.48 \\
\hline & & YX & $y=0.044 x-65.278$ & 0.542 & 0.000 & 0.49 \\
\hline \multirow[t]{12}{*}{ Rooting stage } & \multirow[t]{6}{*}{$S$} & $\mathrm{AR}$ & $y=1.416 x-2736.073$ & 0.284 & 0.000 & 27.27 \\
\hline & & GY & $y=2.124 x-5138.878$ & 0.418 & 0.000 & 30.40 \\
\hline & & $\mathrm{JH}$ & $y=1.808 x-3520.986$ & 0.308 & 0.000 & 32.87 \\
\hline & & LW & $y=2.617 x-5138.397$ & 0.405 & 0.000 & 38.48 \\
\hline & & $\mathrm{YZ}$ & $y=1.195 x-2307.352$ & 0.212 & 0.002 & 27.91 \\
\hline & & YX & $\mathrm{y}=6.694 \times 10^{-121} \ln (\mathrm{x})^{36.995}$ & 0.331 & 0.000 & 0.32 \\
\hline & \multirow[t]{6}{*}{$\mathrm{T}$} & $\mathrm{AR}$ & $y=0.092 x-168.657$ & 0.468 & 0.000 & 1.19 \\
\hline & & GY & $y=0.096 x-176.709$ & 0.444 & 0.000 & 1.30 \\
\hline & & $\mathrm{JH}$ & $y=0.085 x-153.524$ & 0.392 & 0.000 & 1.28 \\
\hline & & LW & $y=0.069 x-122.566$ & 0.302 & 0.000 & 1.27 \\
\hline & & $\mathrm{YZ}$ & $y=0.076 x-135.684$ & 0.357 & 0.000 & 1.23 \\
\hline & & YX & $y=0.083 x-151.706$ & 0.433 & 0.000 & 1.16 \\
\hline \multirow[t]{7}{*}{ Flourishing stage } & $S$ & LW & $y=1.563 x-2974.449$ & 0.109 & 0.035 & 54.17 \\
\hline & \multirow[t]{6}{*}{$\mathrm{T}$} & $\mathrm{AR}$ & $y=0.032 x-42.523$ & 0.161 & 0.009 & 0.90 \\
\hline & & GY & $y=0.042 x-61.200$ & 0.251 & 0.001 & 0.87 \\
\hline & & $\mathrm{JH}$ & $y=0.030 x-38.106$ & 0.154 & 0.011 & 0.86 \\
\hline & & LW & $y=0.032 x-41.236$ & 0.185 & 0.005 & 0.81 \\
\hline & & $\mathrm{YZ}$ & $y=0.039 x-55.293$ & 0.265 & 0.001 & 0.79 \\
\hline & & YX & $y=0.034 x-46.061$ & 0.187 & 0.005 & 0.86 \\
\hline \multirow[t]{7}{*}{ Maturing stage } & \multirow[t]{3}{*}{$S$} & $\mathrm{AR}$ & $y=-1.697 x+3690.704$ & 0.126 & 0.023 & 54.13 \\
\hline & & $\mathrm{YZ}$ & $y=-1.646 x+3560.366$ & 0.137 & 0.017 & 50.19 \\
\hline & & YX & $y=-2.211 x+4724.763$ & 0.245 & 0.001 & 47.11 \\
\hline & $\mathrm{T}$ & $\mathrm{YZ}$ & $y=0.021 x-15.534$ & 0.144 & 0.014 & 0.63 \\
\hline & \multirow[t]{3}{*}{$\mathrm{P}$} & $\mathrm{AR}$ & $y=4.885 x-9456.659$ & 0.131 & 0.020 & 152.91 \\
\hline & & $\mathrm{JH}$ & $y=3.230 x-6191.652$ & 0.117 & 0.029 & 107.83 \\
\hline & & $\mathrm{YZ}$ & $y=3.526 x-6755.833$ & 0.124 & 0.024 & 113.589 \\
\hline
\end{tabular}


the optimal values. Precipitation was $789 \mathrm{~mm}$ in GY, $758 \mathrm{~mm}$ in JH and $794 \mathrm{~mm}$ in YX, within the optimal value, but $\mathrm{P}$ was $821 \mathrm{~mm}$ in AR, $827 \mathrm{~mm}$ in LW and $811 \mathrm{~mm}$ in YZ, higher than the optimal value. Long et al. (2003) reported that the optimal precipitation (P) for high quality tobacco of overseas regions is $89.8 \sim 138.3 \mathrm{~mm}$ in rooting stage, $124.6 \sim 163.8 \mathrm{~mm}$ in flourishing stage and 114.2 162.9 $\mathrm{mm}$ in maturing stage., In the six counties in Chenzhou City, P was $227 \sim 250 \mathrm{~mm}$ in rooting stage, $258 \sim 285 \mathrm{~mm}$ in flourishing stage and $269 \sim 314 \mathrm{~mm}$ in all counties in Chenzhou City indicating that all values were higher than those of the optimal values. The optimal sunshine hours in maturing stage was reported to be 280 300 hrs (Yang et al. 1987), S in this stage was $297 \mathrm{hrs}$ in AR and YZ, $291 \mathrm{hrs}$ in JH, $294 \mathrm{hrs}$ in LW, and $290 \mathrm{hrs}$ in YZ, within the optimal value, and S was 309 hrs in GY, higher than the optimal value.

Li et al. (2013) reported that the values of S from 1956 to 2005 in China showed a significant decreasing tendency (decreased by 0.012 0.023 hrs/y), T from 1951 to 2009 in China showed a significant increasing tendency (increased by $0.005^{\circ} \mathrm{C} \sim 0.008^{\circ} \mathrm{C} \mathrm{y}^{-1}$ ) (The Second Time National Climate Change Assessment Report Authoring Group, 2011), and P from 1956 to 2015 in southern China showed in general increasing tendency (increased by $1.89 \mathrm{~mm} / \mathrm{y})(\mathrm{He}$ et al. 2017). The same changing tendencies were also found in $\mathrm{T}$ and $\mathrm{P}$ in the present study, but comparatively, $\mathrm{T}$ and $\mathrm{P}$ increased by $0.029 \sim 0.044^{\circ} \mathrm{C}$ y and $0.572 \sim 4.095 \mathrm{~mm} / \mathrm{y}$, respectively. $\mathrm{S}$ also showed decreasing tendency in $\mathrm{YZ}$ and $\mathrm{YX}$, decreased by $0.398 \sim 1.682 \mathrm{hrs} / \mathrm{y}$, but showed increasing tendency in AR, GY, JH and LW, increased by $0.466 \sim 5.534 \mathrm{hrs} / \mathrm{y}$. As for the changes of climate parameters during tobacco field-growth period, S generally showed a significant decreasing tendency (decreased by $1.08 \mathrm{hrs} / \mathrm{y}$ ) and $\mathrm{P}$ showed an insignificant increasing tendency (increased by $1.5 \mathrm{~mm} \mathrm{y}^{-1}$ ) from 1961 to 2010 in Hunan (Zhang et al. 2012), while T showed a significant increasing tendency from 1981 to 2010 (increased by $0.040^{\circ} \mathrm{C} / \mathrm{y}$ ) (Chen et al. 2015a). The above changing tendencies were also found in $\mathrm{T}$ and $\mathrm{P}$ in the present study, $\mathrm{T}$ was significantly increased by $0.037 \sim 0.050^{\circ} \mathrm{C} / \mathrm{y}$ and $\mathrm{P}$ was insignificantly increased by $1.109 \sim 2.774 \mathrm{~mm} / \mathrm{y}$. Sunshine hour also showed a decreasing tendency in AR, YZ and YX, decreased by $0.257 \sim 0.879 \mathrm{hrs} / \mathrm{y}$, but showed an increasing tendency in GY, JH and LW, increased by $0.580 \sim 3.946 \mathrm{hrs} / \mathrm{y}$. As for the changes of climate parameters in different tobacco growth stages, as Chen et al. (2015b) found that, from 1981 to 2010 in Guiyang County, both T and P increased in maturing stage, the same tendencies were found in $\mathrm{T}$ and $\mathrm{P}$ in the present study, which were increased by $0.015 \sim 0.022^{\circ} \mathrm{C} \mathrm{y}^{-1}$ and $2.810 \sim 4.893 \mathrm{~mm} / \mathrm{y}$, respectively.

Moreover, the increasing tendency of $\mathrm{T}$ (Pearson correlation coefficient $>0$, Table 2,) is advantageous in rooting and flourishing stages but disadvantage in maturing stage for tobacco growth in the six counties because the optimal temperature for tobacco growth is $25 \sim 28^{\circ} \mathrm{C}$. Because the optimal $\mathrm{S}$ for tobacco growth is $500 \sim 700 \mathrm{hrs}$ in field-growth period, so the decreasing tendency of $\mathrm{S}$ in AR, YZ and YX (Pearson correlation coefficient $<0$ ) is disadvantageous but the increasing tendency of $\mathrm{S}$ in GY, JH and $\mathrm{LW}$ (Pearson correlation coefficient $>0$ ) is advantageous. The optimal $\mathrm{P}$ for tobacco growth was $700 \sim 800 \mathrm{~mm}$ in field-growth period, and the corresponding $\mathrm{P}$ was $821 \mathrm{~mm}$ for AR, $789 \mathrm{~mm}$ for GY, $827 \mathrm{~mm}$ for LW, $811 \mathrm{~mm}$ for YZ and $794 \mathrm{~mm}$ for YZ, so the increasing tendency of $\mathrm{P}$ in these counties (Pearson correlation coefficient $>0$ ) is disadvantageous for tobacco growth. In maturing stage, the optimal $\mathrm{S}$ for tobacco growth is 280 300 hrs, S in maturing stage was $309 \mathrm{hrs}$ in GY and $302 \mathrm{hrs}$ in YX. So the decreasing tendency of S (Pearson correlation coefficient $<0$ ) is advantageous for tobacco growth. The optimal $\mathrm{P}$ for tobacco growth was $250 \sim 300 \mathrm{~mm}$ in maturing stage, and $\mathrm{P}$ was $314 \mathrm{~mm}$ in maturing stage in AR and LW, so the increasing tendency of P (Pearson correlation coefficient $>0$ ) is disadvantageous for tobacco growth. 
The present study also showed that different climate parameters changed differently in different regions and on different time scales in Chenzhou City, for examples, S changed irregularly in all six counties on the scales of year, field-growth period and growth stages except in maturing stage in LW $(\mathrm{P}<0.05)$, but showed significant decreasing tendency in AR in maturing stage, $\mathrm{YZ}(\mathrm{P}<0.05)$ and $\mathrm{YX}(\mathrm{P}<0.01)$. T showed significant increasing tendency on the scales of year and field-growth period $(\mathrm{P}<0.01)$, but only showed significant increasing tendency in $\mathrm{YZ}$ in maturing stage $(\mathrm{p}<0.05)$. Precipitation showed nonsignificant increasing tendency in all six counties on the scales of year and field-growth period, but showed significant increasing tendency in maturing field in AR, JH and YZ ( $\mathrm{p}<0.05)$ and showed nonsignificant increasing tendency in GY, LW and YX. The above results prove further that the model of climate parameter established in a particular region may not be applicable to other regions, it is necessary to setup the model with its own climate data in order to ensure the accuracy or reliability of the model.

It is apparent from the investigation that the main parameters in the six tobacco-planting counties in Chenzhou City changed differently on different scales of time, in which daily mean temperature in the six counties with tobacco-planting in Chenzhou City had significant positive linear correlation with year and daily cumulative precipitation changed irregularly on the scales of year, field-growth period of tobacco, and rooting and flourishing stages of tobacco, but they changed differently with year in maturing stage in different counties. Daily cumulative sunshine hour in the six counties had significant positive linear correlation with year on the scale of rooting stage, changed irregularly with year on the scale of year, and showed different change tendencies in different counties in flourishing and maturing stages. On the scale of field-growth period, daily mean temperature was lower than the optimal value in rooting and flourishing stages, but higher than the optimal value in maturing stage. Cumulative daily sunshine hour was mostly within the optimal values, cumulative daily precipitation in JH, GY and YX was within the optimal value, but higher than the optimal value in AR, LW and YZ. Cumulative daily precipitations in rooting, flourishing and maturing stages were all higher than the optimal values of overseas regions with high-quality tobacco. In maturing stage, $\mathrm{S}$ was within the optimal value in AR, JH, LW, YZ and YX, but higher than the optimal value in YZ. It is necessary to setup the model with its own climate data for a particular region in order to ensure the accuracy or reliability of the model. Further studies are needed to validate and improve the models established in this study, and attentions should be paid to other climate parameters to ensure the forecasting application of models more precise.

\section{Acknowledgements}

This study was supported by the Project of Chenzhou Company of Hunan Tobacco Company (No. 2019-45). We would like to express thanks to those who helped in soil sampling and analysis.

\section{References}

Chen Y, Zhou QM, Yang HQ, Yang HW and Li HG 2015a. Analysis of the climate characteristics during field growth period of tobacco in producing areas of the typical strong flavor type tobacco leaves in Xiangnan. Chin. Tob. Sci. 36:56-62.

Chen Y, Zhou QM, Yang HQ, Yang HW and Li HG. 2015b. Temperature and precipitation change in flue-cured tobacco growing period in Guiyang and Sangzhi tobacco-growing areas in Hunan Province. Acta Tabac. Sin. 21: 48-55.

Chenzhou Municipal Bureau of Statistics 2018. Chenzhou Statistics Yearbook, Chenzhou. 
He SL, Guo XJ, Li FY, LiN and He XW 2017. Spatiotemporal variation of rainfall and rainfall erosivity in southern China in recent 60 years. Resour. Envir..Yangtze Basin. 26: 1406-1416.

Hunan Agriculture Department 1989. Hunan Soils. China Agriculture Press, Beijing.

Jin XQ, Liu YP, Li QJ and Jin QL 2009. Effects of climatic conditions on growth and development of flue-cured tobacco. Modern Agr. Sci. Technol. 4 : 135-138.

Kong XZ, Li DC, Li WJ, Li HG and Xiao YS 2020. Study on climate changes for flue-cured tobacco growth in Chenzhou city of Hunan province. Agr. Sci. 11: 487-499.

Kuang CF 2009. Climatic characteristics and suitability assessment on tobacco-growing in Chenzhou of Hunan. Modern Agr. Sci. Techno. 17 : 284-285.

Li HQ, Fu ZT, Wen X and Huang JB 2013. Characteristic analysis of sunshine duration change in China during the last 50 years. Climatic Envir. Res. 18:.203-209.

Li LY, Xu YM and Wang SS 2015. Advance in effects of climatic factors on aroma components of flue-cured tobacco. Chin. Tob. Sci. 36(1): 107-113.

Li Q 2000. Researches on the relationship between output value and yield or quality of flue-cured tobacco and their climatic types in China. J. An-hui Norm.U. (In Chinese). 23: 72-75.

Long HY, Liu JL, Xu AG, Li ZH, Zhang WL and Zhang YG 2003.A comparison on climate conditions between China's tobacco planting regions and overseas high quality tobacco planting regions. Acta Tabacaria Sinica. Suppl: 41-47

Luo DS, Wang B and Qiao XY 2019. Explanation of national regionalization of leaves style of flue-cured tobacco. Acta Tabacaria Sinica. 25(4) : 1-9.

Luo JQ, Xiao YS, Zhong Q, Yu JL and He B 2017. Production status and development countermeasures of highly flavored type tobacco leaves in Chenzhou. Hunan Agr. Sci 8: 116-118.

Peng XH, Yi JH and Zhou QM 2009. Advance in effects of climatic conditions on internal quality of flue-cured tobacco. Acta Tabacaria Sinica. 30(1): 68-72.

Rong KD 2013. Analysis of climatic resources and weather service on tobacco production in Chenzhou. Till.Cultiv. 6: 59-60.

Song ZM 2010. Studies on the main characters of flue-cured tobacco and its relationship with climatic factors in recent years in China. Institute of Tobacco, Chinese Academy of Agricultural Sciences, Qingdao.

The Second Time National Climate Change Assessment Report Authoring Group 2011. The Second Time the National Climate Change Assessment Report. China Science Press, Beijing.

Wu Z, Zhu LS and Yi K 2011. Research advance in effects of climatic factors on chemical composition of flue-cured tobacco. Acta Agr. Jiangxi. 23(8) : 79-82.

Xiao HQ, Lu KD, Zhang C and Huang WH 2007. Study on tobacco plant region in Hunan based on GIS technology. Journal of Hunan Agricultural University (Natural Sciences). 33: 427-430

Xie YF, Yang HW and Liu YZ 2006. Effect of climatic factors on quality of flue-cured tobacco. A selection of excellent papers from 2004 to 2006 of Yunnan Crop Society. Yunnan Agricultural Science and Technology, Kunming.

Yang SL, Huang ZY, Tang YJ and Wang Y P 1987. A study on the relationship between quality of tobacco and climate in Guizhou Province. Agrometeorol. 12(2): 7-10.

Yu JY and He XX 2006. Data statistical analysis and SPSS application. Posts \& Telecommunications Press, Beijing.

Zhang C, Peng LL, Huang W and Lu KD 2012. Influence of climate change on tobacco planting in Hunan in 1961 to 2010. J. Hunan Agr.U. (Natural Sciences ). 38 : 482-486. 